\title{
ADA APA DENGAN MANAJEMEN SUMBER DAYA MANUSIA DI SIDOARJO
}

\section{Fadila Reni Agustin}

Universitas Nahdlatul Ulama Sidoarjo

Email: fadila.reni17@gmail.com

\section{Manajemen Sumber Daya Manusia}

Manajemen Sumber Daya Manusia adalah segala sesuatu dari bidang manajeman umum yang bertujuan meliputi dari rencana, organisasi, pelaksanaan dan pengendalian. Untuk berperan penting dalam pencapaian tujuan perusahaan atau karyawan. Dan perusahaan perlu adanya memberikan pelatihan, pengembangan terhadap karyawan. Karena karyawan juga perlu mendapatkan perhatian khusus agar jalannya operasional perusahaan sesuai dengan tujuan yang diterapkan oleh perusahaan tersebut. Sumber daya manusia berperan penting dalam pencapaian tujuan perusahaan atau karyawan. Dan perusahaan perlu adanya memberikan pelatihan, pengembangan, terhadap karyawan. Karena karyawan juga perlu mendapatkan perhatian khusus agar jalannya operasional perusahaan sesuai dengan tujuan yang diterapkan oleh perusahaan tersebut. Menurut Purnomo, Putri, \& Rosyidah (2017), Manajemen Sumber Daya 
Manusia adalah tanggung sjawab untuk produktivitas dan hubungan konstruktif organisasi dengan karyawannya.

Sumber daya manusia di wilayah Sidoarjo untuk mengetahui perusahaan-perusahaan yang bisa mencapai tujuan dari perusahaan tersebut. Agar warga di Sidoarjo mendapatkan pekerjaan disetiap perusahaan. Manajemen sumber daya manusia sangatlah penting bagi masyarakat yang tinggal dikota Sidoarjo, seseorang yang mestinya bekerja dalam bidang atau perusahaan seharusnya tahu apa yang diharapkan oleh perusahaan tersebut, maka akan membuka peluang bagi masyarakat lain untuk bekerja atau menjadi karyawan.

\section{Hubungan Manajeman dan Sumber Daya Manusia}

Kabupaten Sidoarjo memiliki beberapa julukan. Salah satu julukan kabupaten Sidoarjo adalah kota udang karena terkenal dengan tangkapan nelayannya. Letak Sidoarjo dianggap cukup strategi ssebab kota ini berdekatan dengan kota metropolitan kedua di Indonesia yakni, Surabaya. MSDM (ManajemenSumberDayaManusia) digunakan sebagai penunjang untuk perekonomian di Sidoarjo.Dengan adanya MSDM yang bagus, maka akan dapat meningkatkan perekonomian pula. Kegiatan tersebut digunakan dalam kehidupan sehari-hari, karena dengan kemajuan jaman, tentunya standart yang diperlukan atau diberikan juga berkembang.Pemerintah sendiri juga sudah 
banyak melakukan pelatihan, seminar, dan penyuluhan yang dimaksudkan untuk para pengusaha-pengusaha yang ada di wilayah Sidoarjo sehingga mereka dapat memperbaiki kwalitas SDM yang mereka miliki (Asitah et al., 2018).Menurut James

\section{A.F.Stoner(2006:Organisasi.org),manajemen}

adalah suatu proses perencanaan, peroganisasian, kepemimpinan, dan pengendalian upaya dari anggota organisasi serta penggunaan semua sumber daya yang ada pada organisasi untuk mencapai tujuan organisasi yang telah ditetapkan sebelumnya. Tujuan manajemen sebagai usaha bersama dengan beberapa orang dalam berorganisasi. Adapun fungsi dari manajemen ada tiga, yaitu: 1) planning (perencanaan), 2) organizing (pengorganisasian), 3) directing (pengarahan). Unsur dari manajemen meliputi : manusia, uang, bahan, mesin, metode, dan pasar.

Sonny Sumarsono $(2003, \mathrm{~h}$ 4) Sumber daya manusia atau human recources mengandung dua pengertian. Pertama adalah usaha kerja atau jasa yang dapat diberikan dalam proses produksi. Dalam hal lain SDM mencerminkan kualitas usaha yang diberikan oleh seseorang dalam waktu tertentu untuk menghasilkan barang dan jasa. Pengertian kedua, SDM menyangkut manusia yang mampu bekerja untuk memberikan jasa atau usaha kerja tersebut. Mampu bekerja berarti mampu melakukan kegiatan yang mempunyai kegiatan ekonomis, yaitu bahwa kegiatan tersebut 
menghasilkan barang atau jasa untuk memenuhi kebutuhan masyarakat.

Setiap warga di wilayah Sidoarjo perlu memahami manajemen dan sumber daya manusia. Sofyandi (2009:6) mengartikanbahwa manajemen sumber daya manusia adalah suatu strategi dalam menerapkan fungsi-fungsi manajemen yaitu planning, organizing, leading,dan controlling,setiap aktivitas operasional sumber daya manusia. Mulai dari proses penarikan, seleksi, pelatihan, pengembangan,dan penempatan yang meliputi promosi, demosi dan transfer, penilaian kinerja, pemberian kompensasi, hubungan industrial, hingga pemutusan hubungan kerja yang ditunjukkan bagi peningkatan kontribusi produktif dari sumbernya manusia organisasi terhadap pencapaian tujuan organisasi secara lebih efektif dan efisien.

\section{Kesadaran Manajemen Sumber Daya Manusia}

Kesadaran akan manajemen sumber daya manusia sangatlah penting bagi masyarakat yang tinggal diSidoarjo. Seseorang yang mestinya bekerja dalam bidang atau perusahaan seharusnya tahu apa yang diharapkan oleh perusahaan tersebut, maka akan membuka peluang bagi masyarakat lain untuk bekerja atau menjadi karyawan.

Freud berpendapat bahwa kesadaran manusia bagian kecil jalannya kehidupan psikis makhluk 
hidup, sehingga hubungan atau perundingan antara kesadaran dan ketidaksadaran dalam kehidupan lebih banyak dilalui dengan ketidaksadaran.

MSDM dapat dibangun dengan senantiasa harus selalu berpegang teguh pada sifat yang dimiliki oleh Rasul yaitu jujur, amanah, fathana, siddiq selain itu juga harus bermodal ikhas, karena Allah ingin agamanya itu di amalkan, poin yang kedua yaitu do'a para alim dan ulama terdahulu lah yang sangat penting dan point yang ke tiga yaitu transparan kepada semua orang agar sesuatu yang di kerjakan mendapat kepercayaan dari orang lain (Munjidah, et al., 2017).

\section{Kesimpulan}

Manajemen sumber daya manusia adalah segala sesuatu dari bidang manajeman umum yang bertujuan meliputi dari rencana, organisasi, pelaksanaan, dan pengendalian. Untuk berperan penting dalam pencapaian tujuan perusahaan atau karyawan. Dan perusahaan perlu adanya memberikan pelatihan, pengembangan terhadap karyawan.Karena karyawan juga perlu mendapatkan perhatian khusus agar jalannya operasional perusahaan sesuai dengan tujuan yang diterapkan oleh perusahaan tersebut.

Sumber daya manusia berperan penting dalam pencapaian tujuan perusahaan atau karyawan. Dan perusahaan perlu adanya memberikan pelatihan, 
pengembangan terhadap karyawan. Karena karyawan juga perlu mendapatkan perhatian khusus agar jalannya operasional perusahaan sesuai dengan tujuan yang diterapkan oleh perusahaan tersebut.

\section{References}

Asitah, N., Maula, I., Munjidah, A., Nahdiyah, K., Yuniarti, D., Sholichah, S. A., Purnomo, A., Rosyidah, E., Anam, Fatkul., Achmadi, A.A., Fahmi, M. (2018, May 25). Urgensi Aktualisasi Manajemen Sumber Daya Manusia untuk Resurgensi Perekonomian di Sidoarjo. http://doi.org/10.17605/OSF.IO/TG79P

Herman,Sofyandi.2009.Manajemen Sumber Daya Manusia.terjemahan.Jakarta,PT.Prenhallindo.

Munjidah, A, Zannah, I.P.N., Purnomo, A., Rosyidah, E. (2017). Ml Thoriqussalam Berpegang Kepada Rosul. In Wirausaha Pendidikan Indonesia (Jilid 4). Sidoarjo: Unusida Press.

Purnomo, A., Putri, R. A., \& Rosyidah, E. (2017). Kamus Manajemen Sumber Daya Manusia. Sidoarjo: Unusida Press.

Stonner, James, A.F.1996.Manajemen.Edisi II.Prenhalindo.Jakarta 
Sumarsono,sonny.2003.Ekonomi Sumber Daya Manusia dan Ketenagakerjaan.Yogyakarta:Graha IImu 